CZU: 821.135.1-93(478).09

https://doi.org/10.52505/lecturi.2021.05.19

\title{
GRIGORE VIERU: POEZIA PENTRU COPII ŞI POEZIA DESPRE COPII
}

\author{
Cristian SERDEȘNIUC \\ Şcoala Doctorală Științe Umanistice, USM, Chișinău
}

Rezumat. Grigore Vieru debutează editorial cu o plachetă de versuri consacrate copilului și copilăriei. Prin poezia sa despre (și pentru) copii, poetul îl ajută pe cititorul mic să descopere orizonturile vieții și, totodată, să se descopere pe sine. Poetica viereană nu s-a despărțit de filonul copilăriei nici în abordarea temelor pentru maturi. Creația viereană se încadrează în cele două tipare ale literaturii: pe de o parte poezia pentru copii, prin care înțelegem o literatură pentru toată lumea, pe de altă parte, o poezie despre copii, care este inspirată din universul infantil al ludicului, mirajului și al afecțiunilor puerile. Dezmembrată concludent de conjuncturile regimului ideologic, impuse presant în literatura basarabeană sovietică, creația lui Grigore Vieru a râvnit insistent spre emancipare estetică. Anume poezia sa a marcat sugestiv revigorarea lirismului postbelic in literatura română din Basarabia.

Cuvinte-cheie: Poezie viereană, copil, copilărie, lirism, principiu estetic, regim ideologic, literatură pentru copii.

Abstract. Grigore Vieru debuts with a booklet of poems dedicated to children and childhood as well. By his poem about (and for) children, the poet helps to little reader to open the horizons of their life and also to discover his own. Vieru's creation never has spited up from childhood direction, even when he applies for adults themes. Vieru's creation blends those two literary paradigms, on the one hand, rhymes for children, that means the literature for entire world, from the other hand, the poem about children, which were inspired by infantile universe of playfulness, marvel and of affection of childishness. Clinching detached from ideological conditions of authorities, pushing under the pressure of Bessarabian Literature of the Soviets, the oeuvre of Grigore Vieru coveted insistently through aesthetic emancipation. Certain his poems suggestive marked the revival of postwar liberalism in the Romanian literature in Bessarabia.

Keywords: Vierean poetry, child, childhood, lyricism, aesthetic principles, ideological regim, the literature for the children.

Spre deosebire de știință, literatura este o artă ce se ocupă de relevarea esteticului și căutarea marilor rosturi umane. De-a lungul istoriei, literatura a demonstrat că posedă funcția comunicativă între generații. De la scrierile religioase 
și de orientare mitico-folclorică până la e-poezia postmodernistă, literatura este dovada evoluției intelectuale și spirituale a omului pe pământ. Obiectiv sau subiectiv, sub semnul posibilului sau al imaginarului, literatura a ,proiectat" omul aflat în faţa circumstanțelor realităţilor de epocă. Fie pentru maturi, fie pentru copii sau adolescenți, literatura a contribuit semnificativ la formarea și dezvoltarea personalităţii umane. Operele literare destinate cititorului matur au la bază filonul experienței umane: momente autobiografice, evenimente memorabile, confesiuni, meditări, reverii ș.a., pe când scrierile pentru copii plăsmuiesc frumusețea universului utopic al copilăriei, locul de vrajă, de încântare și desfătare puerilă. Scriitorii apelează la registrul ideatic al copilăriei pentru a reda prospețimea, sensibilitatea și neprihănirea vârstei umane a copilului, jocul și ritualul cunoașterii cu universul înconjurător. Prin poezia despre (și pentru) copii, cititorul mic descoperă orizonturile vieții și, totodată, se descoperă pe sine.

Criticul literar şi teoreticianul George Călinescu e de părere că literatura pentru copii nu se adresează numai cititorului mic, ci și celor maturi, pentru că copilăria nu dispare niciodată din noi, ea constituie izvorul permanent din care decurg toate meandrele vieții noastre (1964, p. 274). Teoreticianul susține faptul că o literatură exclusiv pentru adulți e limitată, falsă și specializată. Și tot așa numai pentru copii (ibidem, p. 274). Pe de cealaltă parte, criticul literar Hristu Cândroveanu crede că ar trebui de făcut o delimitare clară între literatura despre copii și literatura pentru copii. Prin literatura pentru copii înțelegem o literatură pentru toată lumea, pe când literatura despre copii este inspirată din universul acestor vârste, ori străbătut de, stăpânită de acel climat infantil-juvenil, în care sentimentele etice sunt atât de la ele acasă (Andrei, 2006, p. 7).

În literatura română basarabeană atestăm acest fenomen artistic bine vădit în creația lui Grigore Vieru, Liviu Damian, Spiridon Vangheli ș.a. Această delimitare nesemnificativă pentru critica literară ne ajută să înțelegem încotro se îndreaptă poezia lui Grigore Vieru sau proza lui Spiridon Vangheli, unul despre copilărie, iar celălalt pentru copilărie?! Totuși, analizând și sintetizând poeziile vierene în care se prezintă universul copilăriei, desprindem un lucru surprinzător și important: poezia lui Grigore Vieru implică ambele componente ale formulei lui Cândroveanu. Pe de o parte, Grigore Vieru creează o poezie pentru copii, simplă, accesibilă și ușor memorabilă, de altfel, o poezie jucăuşă. Pe de altă parte, poezia viereană pentru copii face o referire clară asupra faptului că poetul rememorează artistic secvențe ale copilăriei proprii, marcate ostil de conjuncturile istorice de epocă.

Pornind de la afirmațiile lui Nicolae Manolescu, precum că literatura pentru copii trebuie să cuprindă folclorul jocurilor copilărești, proza de aventură, versurile pentru cei mici, menite recitării (ibidem, p. 8), constatăm cu fermitate că Grigore Vieru este un maestru al poeziei în acest sens. Poezia viereană pentru și despre 
copii împletește armonios un spectru larg de elemente poetice: accesibilitatea și simplitatea versului, cantabilitatea, melodicitatea, ritmicitatea, cromatica și imagistica tablourilor sugerate, plasticitatea și prospețimea expresiei poetice, dar și naturalețea. Într-o perioadă de restriște presantă în literatura basarabeană postbelică, poezia lui Grigore Vieru reușește să își păstreze fiorul seninătății, jovialității și-al unui cadru serafic intim copilului. Pentru Grigore Vieru este important ca acest mediu fabulos, în care conviețuiește copilul și natura înconjurătoare, să rămână întotdeauna un univers infantil.

Se cunoaște bine faptul că Grigore Vieru este un poet al tradițiilor, iar poezia sa manifestă o intensă confluență folclorică. Folcloristica viereană are în vedere păstrarea legăturii organice a umanității cu sorgintele strămoșesc. Într-o modalitate epatantă, Grigore Vieru contemplează o lume rurală pe care o sacralizează prin ochi de copil. În poezia viereană pentru maturi, folcloristica se regăsește prin orientarea poeziei spre baladesc, mitizarea dorului, sacralizarea arborelui și a femeii, sacralizarea izvorului, a spațiului celest și umanizarea universului necuvântătoarelor. Pe de cealaltă parte, și în creația viereană pentru copii se atestă elemente folclorice accentuate, care iau naștere din ritualul jocurilor copilărești. În istoria literaturii române, folclorul constituie un gen de sine stătător care îl însoțește pe copil în toate manifestările, dezvoltându-se de-a lungul secolelor în strânsă legătură cu jocurile lor și educația pe care o primeau în familie (Istoria literaturii române, 1964, p. 180). Jocul copilului vierean este cu totul de o altă natură. Acesta este invitat să danseze alături de fluturi și păsărele, să exploreze misterul aventurilor alături de soare și de stele, să descopere tainele adevărului alături de micile necuvântătoare, să asiste la dansul picăturilor de ploaie și a fulgilor de nea și să învețe jucându-se: „,Vine ploaia peste lunci/ $\mathrm{Cu}$ picioare-albastre, lungi!/ Pic-pic-pic, pic-pic-pic,/ Grâul crește mare-n spic!// Iată, ca pe țârâieci/ Prind în palme stropii reci:/ „Ploaie, tu de unde știi/ Să crești pâine în câmpii?!" (Ploaia).

Criticul literar Ion Ciocanu remarcă faptul că poezia viereană surprinde cititorul mic prin faptul că stârnește hazul copiilor sau uneori îl răvășește adânc (1998, p. 104). După Ion Ciocanu, Grigore Vieru creează o poezie aproape de inima copilului, prin care poetul reușește să cultive micului cititor un gust lingvistic fin (op. cit.).

Un alt aspect particular pentru creația viereană despre (și pentru) copilărie, aprofundat și în poezia pentru maturi, este utilizarea artistică neîntâmplătoare a mai multor numere și cifre simbolice. Grigore Vieru recurge la simbolistica numerelor pentru a reda anumite realități lumești sau pentru a face comparații alegorice. Cele mai multe poezii de acest tip au fost puse pe melodie și s-au folclorizat cu uşurință. De exemplu: „Are mama doi feciori:/ Două sfinte sărbători,/ Două sărbători în casă,/ Nu știu care-i mai frumoasă,/ Feciorașii mei, feciori’” (Are mama doi feciori); 
„Frunză verde, lăcrămioare,/ Suntem două surioare” (Suntem două surioare); „Fugafuga, prin câmpii,/ Fuga-fuga, doi copii:/ Două păsări fără de griji!” (Fuga-fuga); „Trei vieți/ Aș vrea să tot trăiesc (...)/ Inimi trei/ Să-ți cânte gloria (...)/ De zece ori la rând/ Pentru al tău/ Fermecător pământ” (Trei vieți); „Trei culori și-o singură iubire/ Românească,/ Trei culori și-o singură vorbire/ Românească" (Trei culori) ș.a. De același succes nu s-a bucurat și poezia „Curcubeul”, fiind dezaprobată și interzisă de autoritățile sovietice din cauza unei simple coincidențe a celor trei culori, considerată o aluzie la culorile tricolorului românesc: „Cârnul - albastrul de cicoare,/ Crețul - galbenul din soare,/ Cel'lalt - roșu și-a ales”. Numărătorile, enumerările, dar și aplicabilitatea poetică a numerelor în creaţia viereană îi conferă poeziei o ritmicitate intensă ce contribuie substanțial la memorizarea rapidă a textelor pentru cititorul de toate vârstele. Aceste aspecte artistice identifică poezia cu un joc de cuvinte, din care se desprind imagini afective. Jocul poetic al cuvintelor vierene îi sugerează cititorului mic o prezentare de ansamblu a universului înconjurător.

Revoluționară pentru literatura anilor '60, creația lui Grigore Vieru se include armonios în cele două extremităti artistice: pe de o parte o poezie jovială pentru copii, pe de cealaltă parte o poezie alegorică pentru cititorul adult. Poezia sa oscilează mereu între cele două țărmuri ale existenței umane: copilăria și maturitatea, iar în centrul lumii fiind pusă ființa sacrală a copilului și nevoia sa primordială de comunicare. Este evident faptul că poezia lui Grigore Vieru se identifică cu un dialog confesiv în care poetul abordează teme majore ale universalității. Chiar de la cântecul pentru leagăn, care a luat naștere din necesitatea practică de a crea o atmosferă de calm, de monotonie, necesară adormirii copilului mic (Istoria literaturii române, 1964, p. 174), Grigore Vieru pune în valoare relația armonioasă dintre mamă şi făt, totodată accentuează despre înțelepciunea și sacralitatea maternă pe care o revarsă necontenit asupra copilului: „Dormi în pace și visează,/ Visul fie-ți nalt și drept/ Ca și plopii ce veghează./ Dormi, voinicul meu deștept,/ Lâng-al mamei piept” (Cântec de leagăn) sau „Hai, puiu, nani-na,/ Că mama te-a legăna,/ Pe obraji, pe geana sa” (De leagăn). Afective și încântătoare, creațiile vierene au cultivat respectul și dragostea dintre părinți și copii. Poetul vrea să-i educe copilului sentimentul recunoașterii pentru o copilărie fericită și fără de grijă, de aceea o bună parte din creațiile sale sunt dedicate în special mamei „Dormi-adormi, măicuță dragă,/ Dorm nepoții tăi de fragă,/ Dorm şi blidele spălate,/ Dorm și rufele curate. (...) Dormi, măicuţa mea albită,/ Dormi, măicuța mea iubită" (Cântec de leagăn pentru mama).

Înțeleasă ca o puternică forță educativă, creația lui Grigore Vieru pentru copii nu este nici pe departe didacticistă. Poetul se opune pregnant asupra ideii de a-i învăța pe copii să crească după modelele canonice ale societăţii. Pentru Vieru este important ca fiecare copil să se simte liber și să gândească natural, să cunoască ghidat legitățile vieții și să-și formeze propriile raționamente. O literatură didacticistă ar 
însemna moartea acesteia, la fel cum o poezie didacticistă ar stagna dezvoltarea armonioasă a personalității copilului. Din aceste considerente, poetul Grigore Vieru renunță la constrângeri, dar militează pentru o poezie menită să promoveze identitatea unică a copilului. În viziunea sa, este inadmisibil ca o literatură pentru copii să fie supusă didacticismului. Creațiile literare didacticiste moralizează excesiv pentru a impune normele indiscutabile, pe când literatura pentru copii trebuie să pună în circulație valori și modalități de gândire prin intermediul ficțiunii, evaziunii, adeseori absurdului (Breaz, 2013, p. 106).

Întreaga creație viereană poate fi definită ca o axă a valorilor supreme: Iubirea, Credința, Adevărul, Binele, Dragostea, Iertarea, Grija, Ascultarea, Smerenia ș.a., care, în cele din urmă, constituie un alfabet valoric vierean. Pe marginea acestor idei se pronunță și cercetătoarea Silvia Negruțiu, care consideră că un asemenea alfabet constituie cheia prin care cititorul pătrunde mesajul educaţional ce conturează o nouă paradigmă educațională, cu puternică încărcătură formativă, care privește înspre un model deschis către toate resursele inteligențelor multiple (2010, p. 109). Grigore Vieru creează acest registru valoric pentru a crește o generație empatetică, umană, întoarsă spre sevele strămoșești. Greu de imaginat, dar într-o perioadă cumplită a totalitarismului, anii '60, '70 și după, Grigore Vieru creează o poezie revigoratoare. Revigorarea lirismului nu s-a produs prin prisma imprimării estetice a realităţii de epocă, ci prin plăsmuirea originală a imaginii copilărești - centrul poeticii vierene. Întâmplător sau nu, Grigore Vieru nu se desparte nici pe o clipă de albia copilăriei. Poetul scrie pentru copii și despre copii. Pentru copii a lăsat cele mai îndrăgite versuri („Alarma”, „Albinuța”, „Abecedarul” ș.a.) care s-au folclorizat cu ușurință, unele fiind traduse și în alte limbi. Pentru cititorul matur a scris poezii profunde, marcate de experiențe umane și probleme grave ale societății. Lumea copilăriei vierene supraviețuiește și în poezia pentru adulți. Dorul de a se reîntoarce în copilărie este mai puternic și simţitor atunci când poetul rămâne „orfan” și de mamă (Litanii pentru orgă). Poetul nu face o delimitare clară a vârstelor umane, decât să accentueze minunăția și singularitatea copilăriei. Universul poetic vierean nu aparține copiilor sau adulților, el aparține tuturor, pentru că din creațiile sale se desprind adevăruri umane.

O trăsătură artistică intrinsecă în poetica lui Grigore Vieru este profunzimea sensibilității cuvântului. Comunicarea intimă și autentică este întrevăzută între toate „personajele” vierene: copil - natură, copil - mamă, copil - viețuitoarele înconjurătoare, adult - iubita, adult - mama, adult - graiul străbun, omul matur Dumnezeirea și alte ipostaze lirice. Fondul intim vierean s-a fundamentat pe baza trăirilor proprii: copilăria însingurată, adolescența ispititoare, maturitatea vulcanică și, s-ar cere fără dor și poate, dorința de reîntoarcere în copilărie. Astfel vorbind, întregul demers poetic al său poate fi privit ca o parabolă matematică, pe de o parte 
copilăria biologică, pe de cealaltă parte - copilăria spirituală sau copilăria intimă: „Am îmbătrânit./ Scriu caligrafic și mășcat/ Ca în primul an de școală./ În fiecare dimineață/ Îmi bate la geam/ Copilul care am fost./ Suflu în florile de gheață/ Să văd cine-i./ Sunt fericit/ Că am fost copil” (Copilul care am fost). Atașamentul poetului pentru copil și copilărie nu dispare nici în poezia meditațiilor adulte. Prin chipul copilului Grigore Vieru se reîntoarce la casa părintească, locul sacral de unde iau naștere cele mai importante învățături umane. Aici, în sânurile părintești, în satul de unde a pornit în marea sa devenire, copilul vierean a avut cei mai erudiţi dascăli: graiul matern, murmurul de izvor, țăranul în câmp, cuibul de rândunică, pomul de lângă fereastra casei și, nu în ultimul rând, tradițiile seculare ale sătenilor. Grăuntele erudiției neamului a prins rădăcini adânci în poezia viereană pentru toate vârstele, toate descoperite prin miracolul mirării copilărești, păstrat de Grigore Vieru cu mare sfințenie pe tot parcursul vieții sale.

Copilăria este o formă artistică insolubilă în creația lui Grigore Vieru. Tema copilăriei se împletește organic cu tema naturii, a mamei, a graiului străbun, a iubirii și a patriotismului. Copilul, în viziunea poetului, este protectorul inocenței umane pe pământ. Prin reflectarea copilărescului Grigore Vieru nu doar sensibilizează cititorul, ci imortalizează anumite stări ale umanității. Toate drumurile destinului pornesc din copilărie, tărâmul spre care o viață-ntreagă râvnește poetul, paradisul pierdut pe care Grigore Vieru îl rememorează sub semnul fabulosului. Într-o intervievare cu Efim Bivol, Grigore Vieru mărturisește că un copil este frumos prin faptul că nu-i este caracteristică urâțenia relațiilor dintre oameni și că nu cunoaște răutatea și mizeria politică. Un copil ar putea să se roage dimineața și seara lui Dumnezeu, pentru că însăși ființa lui este o rugăciune prin puritatea și nestricăciunea sufletului său (Bivol, 2005, p. 2). Pe de altă parte, poetul își declară în nenumărate rânduri predilecția pentru lumea infantilă, menționând despre importanţa omului de a-și păstra, pe tot parcursul vieții, copilul din sine: „A crește înseamnă a nu lăsa copilul din tine să moară. Să lăsăm copilului din noi mărul roșu al inimii, căci mărul este al lui'”(Vieru, 1989, p. 19).

Problema artistică a poeticii vierene despre copil și copilărie este cercetată îndeosebi de exegetul Mihai Cimpoi. Începând cu monumentala monografie „Mirajul copilăriei” (1968) criticul relevă în creația lui Grigore Vieru un spectru vast de particularități estetice inedite pentru literatura basarabeană şaizecistă. În primul rând exegetul remarcă capacitatea poeziilor vierene de a-l fascina cu ușurință pe cititorul mic și de a-i înțelege naivitatea. Pe de altă parte, Grigore Vieru creează o poezie în care copilul este meșterul fanteziei sale. După Cimpoi, copilul reface realitatea în felul său, o modifică conform unei logici primitive, dar fidelă cu sine $(1968$, p. 7). În al treilea rând, hotarul dintre copilărie și realitate este marcat de ritualul jocurilor puerile, căci prin joc copilul pășește în tainele universului, cunoaște 
lumea și se cunoaște pe sine. Spațiul natural și artificial, pe care-l sugerează poetul, este inofensiv. Copilul este ademenit prin vraja tablourilor familiale, intime firii sale. În acest mediu sigur și amiabil, Mihai Cimpoi observă faptul că copilul lui Vieru nu simte însă nevoia de a fugi, căci este în mijlocul naturii, în intimitatea ei vrăjită. Singura acțiune la care este chemat este aceea de a-i asimila și de a-i intensifica frumusețea printr-o modelare estetică $(2009$, p. 80) „Unu, doi, trei,/ Eu strâng flori de tei./ Patru, cinci, șase,/ Florile miroase./ Șapte, opt, nouă,/ Florile-s cu rouă./ Am ajuns la zece,/ Roua este rece!" (Numărătoare).

Grigore Vieru este un poet inseparabil de tărâmurile imense ale copilăriei. Poetul le cercetează și le explorează râvnitor și în filozofia maturității depline. Prin intermediul poeziilor pentru și despre copii și copilărie, poetul a reușit să salveze patria, limba și identitatea națională. Din substraturile versurilor pentru copii se desprind comportamente mature, sfaturi și îndemnuri uşor aluzive pentru păstrarea ființei naționale în vremurile de restriște de sub ocupația sovietică. Prin poezia sa îngăduitoare a supraviețuit spiritul neamului, adevăratele valori, tradițiile și obiceiurile străbune. Oricât de mult n-ar înainta poetul spre dimensiunile estetice ale literaturii, Grigore Vieru mereu se întoarce spre limanurile paideumei copilăriei. E adevărat că, după Theodor Codreanu, Grigore Vieru nu a reușit peste tot să rămână sub ploaia curată a copilăriei, dar performanțele îl arată ca fiind o legătură organică, paideumică, între cele două filoane lirice (2004, p. 252). Criticul recunoaște că existența copilăriei în poezia vierenă se datorează păstrării copilului din fiinţa poetului. Pe de cealaltă parte, poezia pentru copii își păstrează farmecul și esența artistică atâta timp cât copiii sunt tratați ca niște oameni întregi (ibidem, p. 253).

Promotor arzător pentru lumea și misterele copilăriei, Grigore Vieru nu poate fi considerat un poet ,prizonier” al nematurității. Criticul Theodor Codreanu admite ideea că unele voci ale criticii literare, în special a literaturii „moldovenești” sovietice, ar specula opinii precum că Grigore Vieru este un poet primitiv rămas în arealul infantilismului, adică pe treapta orală. Teoreticianul Sigmund Freud vede copilăria ca pe o preistorie individuală (1990, p. 190). Raportând ipotezele lui Sigmund Freud asupra arguțiilor despre rudimentaritatea creaţiei vierene, putem constata faptul că poezia lui Grigore Vieru este puternic determinată de amintiri (auto)biografice conservate în copilăria fragedă. După Freud, primii ani ai copilăriei sunt cei mai importanți, pentru că constituie o trăsătură arhaică importantă a visului (ibidem, p. 191). O altă explicație a fenomenului copilăriei din creaţia viereană este argumentat prin faptul că educaţia primită în prima copilărie lasă cele mai adânci amprente (ibidem, p. 294). Suntem de acord că creația lui Grigore Vieru este puternic marcată de evenimentele istorice de epocă: însingurare, suferință, război, frică ș.a. Freud întrevede că aceste amprente cauzează nevroze acute, iar în maturitate anxietate. 
O altă idee genială, destul de importantă pentru studiul nostru, este afirmația lui Freud precum că prin vis copilul continuă să trăiască în omul adult, cu particularitățile și dorințele sale, chiar cu acelea care mai târziu au devenit în viață inutile (Freud S., op. cit.). În poezia lui Grigore Vieru copilul supraviețuiește datorită încărcăturii afective pe care o preia din mediul naturii. La el copilăria nu este una individuală sau proprie, ci colectivă, aparținând tuturor generațiilor. Poezia sa se înscrie într-o circumferință a cărui punct de plecare și de venire este universul mirific al copilăriei. Aceasta s-ar explica în felul următor: până în anul 1968 Grigore Vieru scrie pentru copii, apoi urmând o etapă de creație în care poetul plăsmuiește o ființă vegetală romantică (Codreanu Th., ibidem), cea de-a treia etapă constând în reîntoarcerea întârziată în copilărie sau căutarea paradisului pierdut. Indiferent cui îi este consacrată sau în parametrii etici și artistici ai cărei vârste se încadrează, poezia, după Grigore Vieru, trebuie să rușineze sufletul sărac, să-1 pedepsească chiar prin statutul ei estetic, prin taina frumosului pe care-1 promovează (Grosu, 2015, p. 22).

Opera lui Grigore Vieru despre copilărie, în special copilăria prin filiera rememorării evenimentelor dramatice, poate fi interpretată din perspectiva psihocriticii. După Anatol Vântu, elementele distinctive care confirmă semnele psihocriticii în creaţia lui Grigore Vieru sunt: viziunea maternă asupra Universului, programatica ,întoarcerea la izvor”, motivul fundamental al lacrimii, cât și apariția în diferite volume a acelorași poezii vierene (2005, p. 93). Elementele demersului psihocritic în poezia viereană îl definesc pe Grigore Vieru ca un creator de mituri personale: Mama, Frunza, Izvorul, Dorul, Copilăria ș.a. O bună parte din simbolurile vierene preiau valoarea de mit datorită valorii arhetipale a copilăriei, iar copilăria, în viziunea lui Anatol Vântu, reprezintă o contopire a celor două lumi: mitul și realitatea (op. cit.). Mitul personal s-a cristalizat în creația lui Vieru ca o consecinţă a rupturii sale lăuntrice, singurătatea copilărească, lupta în maturitate faţă-n față cu teroarea politică, arderea în numele idealului uman, precum și dorinţa nestăvilită de desăvârșire spirituală. Toate aceste elemente poetice, cunoscute ca arhetipuri vierene, au plăsmuit în ființa cititorului germenele omenescului.

Poezia viereană pentru copii a constituit o formă intimă de comunicare între poetul surghiunit lingvistic și limba română. Înţelegem clar că poezia pentru copii a însemnat o modalitate de a se ascunde de după cortina literaturii ideologice care era menite să cultive sentimentul de mândrie pentru comunismul socialist. Poezia lui Grigore Vieru exteriorizează stări ale copilăriei bine portretizate. Pentru a-i înțelege însă sensul deplin al cuvântului, este nevoie de cunoștințe istorice vaste. Chiar de la debutul său literar, cu placheta de versuri „Alarma” (1957), Grigore Vieru încearcă să scoată literatura română basarabeană de sub dezghețul sovietic. Cercetătoarea Mihaela Cojocaru se referă la ciclul de poeme „Moșul din leagăn”, unde observă 
două poezii care au o semnificație patriotică explicită: Frumoasă-i limba noastră şi Curcubeul (2004, p. 145). În viziunea cercetătoarei, în acest volum se celebrează patriarhalitatea raporturilor dintre locuitorii Basarabiei, relațiile lor de înfrățire cu natura înconjurătoare (ibidem, p. 145).

Ancorată în albia copilăriei, poezia lui Grigore Vieru îl pune pe cititorul său față-n față cu fenomenul disociației, pe de o parte experiența eului liric, pe de altă parte regăsirea personală sub tiparele altor personaje. Prin lectură copilul poate realiza o binevenită dedublare a sa atunci când se recunoaște în altul (Bratu, 1977, p. 15). Copilul este atras de comportamentul surprinzător al tipajelor artistice, de regulă al necuvântătoarelor, de spațiul cosmic, de universul epatant al naturii rurale. Simpatizând aceste personaje, copilul se vrea alături de ele, încercând să le imite în totalitate: „Zum-zum-zum, cu mare zor,/ Unde vreau, acolo zbor!/ Nu mă-ntreabă niciun om/ De ce stau la el în pom" (Albina).

Militant pentru valorile autohtone, în special pentru limba română și ființa națională, Grigore Vieru creează un personaj copilăresc văzut într-o dublă ipostază. Pe de o parte este afectuos, sincer și neprihănit, dornic să cucerească culmile universului. Pe de cealaltă parte, copilul vierean se impune în lupta cu ,orizonturile roșii" (Casangiu, 2007, p. 43) ale literaturii postbelice din Basarabia Sovietică. În condițiile în care principiul ideologic înlocuiește principiul estetic, iar cenzura proletcultistă s-a răsfirat impunător, copilul vierean păstrează spiritul literaturii autentice, reușind să readucă scrisul poetic la albia lirismului. Constrângerea literară a contribuit la apariția unei literaturi aluzive, o literatură prin care s-a criticat dur mecanismele comuniste. Poezia comunistă a trebuit să formeze viitori partinici, să promoveze doctrinele moscovite și să dezbine spiritul civic adevărat. Poezia lui Grigore Vieru, ,deghizată” într-o poezie pentru învățăcei, a tins spre revenirea literaturii ,,acasă”.

Creația poetică viereană pentru copii se îndepărtează de literatura canonică comunistă și se îndreaptă determinant spre matca literaturii universale consacrată cititorului mic. Poezia lui Vieru proiectează un univers propriu de cunoaștere a copilului, de unde se desprind marile rosturi umane, totodată se pune pe balanța convingerilor Binele și Răul. Frumosul înconjurător este redat prin contactul afectiv al copilului cu mediul naturii. Literatura universală pentru copii își propune să fascineze și să impulsioneze spre Frumos „micul consumator de artă” (ibidem, p. 49), invitându-l să exploreze lumea fanteziei nemărginite. Grigore Vieru gândește o poezie care să cuprindă tot spațiul planetar, demonstrându-i copilului cât de uimitor este ceea ce-1 înconjoară. Desigur, poezia viereană pentru copii se ghidează după niște cerințe ale literaturii pentru copii: accesibilitatea limbajului, personaje ,grăitoare”, ritmicitare melodică, triumfarea binelui și a jovialității, trezirea curiozităţii, caracterul afectiv dens, armonia, naturalețea ș.a. Structural 
simplă, dar amplă după conținut, poezia viereană pentru copii este mereu actuală, e ceea ce scriitorul francez Anatole France apreciază într-o literatură a ,popoarelorcopii'(1943, p. 214), și anume faptul că dacă poezia pentru copii ar îmbătrâni ea ar deveni gravă, savantă și bănuitoare (op. cit.).

Poezia lui Grigore Vieru dintotdeauna şi-a păstrat o particularitate distinctă a muzicalităţii. Însuşirea cantabilităţii versurilor orientează poetica viereană tot mai potenţat spre folclor, în mod special poezia mioriticului de orientare baladescă „Noi suntem oițele,/ Pască-ne fetițele,/ Mâie-ne fetițele/ Numai cu mânuțele” (Bâr, mioriță!). Cercetătorul Victor Ghilaș observă că versul poetului mereu a stimulat imaginația creatorilor/ și a interpreților de muzică (2010, p. 101). Fenomenul muzicalității în creația lui Grigore Vieru a contribuit substanțial la umanizarea unui peisaj natural. Prin sunetul poetic, Grigore Vieru a poetizat stările umane: dorul, iubirea și suferința, bucuria și mângâierea, despărțirea și curajul, dragostea și credința ș.a. Poetul apelează la instrumente muzicale care să confirme originea noastră strămoșească, atribute ale culturii și ființei noastre naționale: bucium, vioară, fluier, flaut, harpă etc.

Lumea lui Grigore Vieru nu este imuabilă. Poetul a umanizat până la cele mai mici și nesemnificative detalii. Artificialul este înlocuit prin natural, lumea necuvântătoarelor obține puterea viului grai, iar copilul vierean este înzestrat cu o viziune magistrală asupra celor lumești. Pentru a se debarasa de însingurare și aprehensiune, poetul creează o senzație permanentă de dialogare. După Mihail Dolgan, lirica lui Grigore Vieru, atât cea pentru copii, cât și cea pentru maturi, se prezintă ca un antrenant și tensionat dialog perpetuu cu subiectul sau obiectul evocat și cu cititorul, ca un continuu formular fie cu întrebări și răspunsuri, fie numai cu întrebări, fie numai cu răspunsuri (2009, p. 227). De la dialogul candid cu firele de iarbă „Tu, iarbă, tot ai mamă?/ De ai - de bună seamă:/ Atunci când înverzești,/ De ea îți amintești” (Tu, iarbă, tot ai mamă?), stele, ploița, curcubeul „Curcubeule vărgat,/ Haide ieși - te-am așteptat demult!/ Nu vezi că la noi în sat/ Ploaia a trecut? (Curcubeul), dezvoltat estetic într-un dialog mirific al cadrului planetar „Mă rog de tine, munte -,/ Cât zboru-o să mă poarte,/ Sărută ochii mamei/ Și-i apără de moarte” (Mă rog de tine), transpus miezos prin filiera emotivității depline „De unde știi, mamă/ Cum arătai tânără/ Când nu ți-ai întipărit/ Pe nicio poză chipul” (De unde știi?...) și a erotismului măsurat ,,- Vreau să te văd, femeie,/ Sau vino să mă vezi,/ Mi-e dor de iarba crudă/ A ochilor tăi verzi” (Vreau să te văd), Grigore Vieru păstrează un cult al armoniei dintre om și cadrul sacral al naturii.

Dezmembrată concludent de conjuncturile regimului ideologic, impuse presant în literatura basarabeană sovietică, creația lui Grigore Vieru a râvnit insistent spre emancipare estetică. Indiscutabil, poezia sa a marcat sugestiv revigorarea lirismului postbelic, poetul identificându-se cu un alt „buzdugan” pentru descendenții săi. 
Reîntoarcerea artistică în copilărie a însemnat pentru Vieru salvarea ființei umane într-o perioadă de declin și restriște națională. Copilul vierean s-a debarasat de grijile revoluționare și a explorat arealul frumosului pilduitor. Astfel, acesta a devenit un catalizator grăitor pentru cititorul dornic să cunoască marile rosturi umane. Poetul n-a insistat, n-a dogmatizat și n-a didacticit cititorul. Poezia viereană sugerează un tablou candid în centrul căruia figurează chipul unui copil dezmierdător, or, nu există o altă cale, decât cea de a păstra copilul din sine, pentru a ne reîntoarce în paradisul pierdut al copilăriei. Prin imaginea copilului, Grigore Vieru cultivă dragostea pentru frumos și pentru maternitate. Totodată, copilul vierean este o sursă prin care poetul inspiră spre sinceritate și adevăr. Poetica lui Grigore Vieru este pătrunsă simțitor de sentimentele unui Poet-Copil, bun cunoscător a misterelor puerile. Grație acestui fenomen literar excepțional, poetul a reuşit să ajungă cu ușurință în inimile cititorului de toate vârstele, în felul acesta atingându-și scopul măreț: „Să-i facă omului clipa mai ușoară și mai frumoasă. Să-1 facă pe om mai bun, mai încrezător în forțele sale. Să-1 facă să-i fie dragă viața, natura din sânul căreia este uneori smuls" (Vieru, 1987, p. 205).

\section{Referințe bibliografice:}

1. ANDREI, Mariana. Introducere în literatura pentru copii. București: Eminescu, 2006.

2. BIVOL, Efim. Puterea curățeniei morale este temelia a toate. În: , $a$ ” MIC”, 2005, nr. 2, pp.2.

3. BRATU, Bianca. Preșcolarul şi literatura. București: Editura Didactică și Pedagogică, 1977.

4. BREAZ, Mircea. Literatura pentru copii. Repere teoretice şi metodologice. Ediția a doua. Cluj-Napoca: Editura ASCR, 2013.

5. CASANGIU, Larisa Ileana. Literatura română pentru copii. Note de curs și sugestii de lecturi plurale ale unor opere. Ed. a II-a, revăzută și adăugită. Constanța: Nautica, 2007. ISBN 978-973-7872-40-1.

6. CĂLINESCU, George. Cronicile optimistului. București: Editura pentru Literatură, 1964.

7. CIMPOI, Mihai. Grigore Vieru, poetul arhetipurilor. Iași: Princeps Edit, 2009.

8. CIMPOI, Mihai. Mirajul copilăriei. Chișinău: Editura „Lumina”, 1968.

9. CIOCANU, Ion. Literatura română contemporană din Republica Moldova. Chișinău: Litera, 1998.

10. CODREANU, Theodor. Duminica Mare a lui Grigore Vieru. București, Chișinău: Litera Internațional, 2004.

11. COJOCARU, Mihaela. Literatura pentru copii. Ploiești: Editura Universității din Ploiești, 2004. ISBN: 973-7965-93-0. 
12. DOLGAN, Mihail. Lirica dialogală la Grigore Vieru și la poetul francez Alain Bosquet. În: Intertext. 2009, nr. 1-2, pp. 227-237. ISSN 1857-3711.

13. FRANCE, Anatole. Le livre de mon ami. Paris: Ed. Hachette, 1943.

14. FREUD, Sigmund. Introducere în psihanaliză. Prelegeri de psihanaliză. Psihopatologia vieții cotidiene. Trad. Leonard Gavriliu. București: Editura Didactică și Pedagogică, 1990.

15. GHILAȘ, Victor. Instrumente muzicale în creația lui Grigore Vieru: simbol și semnificație. În: Akademos, nr. 2(17), 2010, pp. 101-103.

16. GROSU, Liliana. Concepția lui Grigore Vieru despre actul de creație/ textul poetic. În: Buletinul științific al Universității de Stat „Bogdan Petriceicu Hasdeu” din Cahul, Seria „Științe Umanistice”. 2015, nr. 1(1), pp. 20-25. ISSN 2345-1866.

17. Istoria literaturii române, vol. I. București: Editura Academiei, 1964.

18. NEGRUȚIU, Silvia. Mesajul educațional în contextul discursului poetic vierean. Tîrgu Mureș: Universitatea de Arte, 2010, pp. 109-114.

19. VẦNTU, Anatol. Poezia lui Grigore Vieru din perspectiva psihocriticii. În: Metaliteratură. 2005, nr. 12, p. 92-95. ISSN 1857-1905.

20. VIERU, Grigore. Cel care sunt. Chișinău: Literatura artistică, 1987.

21. VIERU, Grigore. Cine crede. Chișinău: Literatura artistică, 1989. 